DOI https://doi.org/10.36059/978-966-397-161-2/141-162

\title{
AREAS OF ACADEMIC STAFF TRAINING IN UKRAINIAN DOMESTIC UNIVERSITIES (1863-1900)
}

\section{Iryna Tamozhska}

\section{INTRODUCTION}

The development of independent Ukraine, democratization of the society, integration into the European and world community require reforming the national system of higher education, which should simultaneously cover all its components - goals, content, forms, technologies, monitoring of academic achievements.

It is impossible to solve these problems without the modernized and intensified training of the academic staff that is capable not only of generating new, relevant and promising directions of scientific and scientific-pedagogical activity, but also of innovative search for alternative personal development models for students of higher pedagogical educational institutions, academic support in students' individual educational trajectories, providing qualified guidance for young scientists, etc.

The aforementioned calls for the need to update the conceptual, theoretical and methodological foundations, content and directions of academic staff training for higher educational institutions, which is stated in the laws of Ukraine "On Higher Education" (2014), "On Education" (2017), "On Scientific and Scientific and Technical Activities" (2015), Regulations "On State Higher Educational Institution" (1996), Pedagogical Constitution of Europe (2013), etc.

Therefore, the development of the system of academic staff training in Ukraine is an integral part of the national state formation, an important factor of national and cultural revival of the country. The current progress of Ukrainian education into the European Higher Education Area and the European Research Area brings forth new tasks of training highly qualified teachers, modernizing the structure of 
educational and scientific qualification levels of the teaching staff in modern higher educational institutions.

Current reformation of the system of higher education in Ukraine requires not only theoretical understanding of new trends in pedagogical science, creative solution of the problem of training the most highly-qualified teaching staff, but also demands a more detailed research, reconsideration and implementation of the experience gained by the leading specialists and educational institutions in the past. We are mostly interested in the periods associated with the emergence of new concepts, approaches, the formation and development of universities. In the history of Ukrainian university education, it is the second half of XIX - the beginning of XX centuries. It is the time of spiritual and cultural revival of the Ukrainian, active reformation of the educational field, the establishment of academic freedoms and values. During this period the content, forms, models of university education underwent intensive development and transformation, which led to changes in the training of university academic staff in accordance with the requirements of the time.

Thus, the problem of scientific and pedagogical training has deep roots and is characterized by ambiguous processes of inheritance of its achievements. In this regard, the need arises for an unbiased analysis of the past experience, which makes it possible to objectively cover the genesis, content, directions of the activities of universities in order to solve the given problem, taking into account the peculiarities of the functioning of universities at different stages of higher education development in Ukraine, identifying factors of the effective work aimed at improving the professional qualification of the university academic staff, in order to creatively use the positive experience of the past in the current environment and prevent failures and defects of previous times.

The topicality and expediency of the research is further enhanced by the need to solve urgent social problems and overcome social and pedagogical contradictions:

- orientation of the modern higher education to the formation of a new generation of Ukrainian intelligentsia and the lack of a 
comprehensive analysis and generalization of the theory and practice of academic staff training at domestic universities;

- between the need for training highly qualified academic staff, capable of conducting pedagogical and research activity in the modern conditions of innovative social development, and insufficient research of the potential of university education as an environment for the professional advancement of scientists-educators;

- between the availability of historical and pedagogical assets revealing the theoretical foundations and the experience of scientific and pedagogical training of the university staff in Ukraine during a certain period of time, which have not lost their scientific and practical significance in modern conditions, and their insufficient application for the aforementioned training in the conditions of current educational reforms in Ukraine.

\section{Expanding the content and areas of academic staff training in the context of the current university reforms (1863-1883)}

Stage I (1863-1883) is a stage of expanding the content and areas of academic staff training in the context of the current university reforms related to the progressive organizational and management changes in the activities of the universities, spreading the levers of their influence in all spheres of university life. The general features of this stage lie in the fact that under the pressure of socio-political and socio-economic transformations of the $1860 \mathrm{~s}$, the restoration of the university autonomy, patterned after the one of 1804 , led to the intensification of the academic staff training.

The results of the scientific search showed that the approaches to the solution of the given problem were partially reflected in such regulatory documents as the Statute of the Imperial Russian Universities (1863), "Regulations on the examination for the title of a full student and academic degrees" (1864), "Rules on the terms and procedure for conducting examinations for the title of a full-time student and academic degrees" (1864), "Regulations on the awarding of academic degrees and titles" (1864). 
The abovementioned documents and the additions to them expanded the theoretical and methodological foundations of academic staff training for master's level in domestic universities: 1) the number of sciences, which determined the specialization of the master, was increased (up to 39); 2) the requirement to send printed copies of the dissertation according to a certain list one month before the public defense, as well as abstracts no more than 4 pages long, was introduced; 3) it was agreed to appoint two official opponents to review the dissertation within a six-month period, as well as to invite scholars of the related sciences from other universities for the public defense; 4) it was recommended to award a master's degree without any examinations to those applicants, who, through their scientific works, had gained worldwide recognition; 5) special honors (symbols) were approved for the those awarded master's degrees.

In the course of the scientific search it was found out that the measures taken contributed to positive changes in masters training. Thus, 39 masters were trained at St. Volodymyr University in the period from 1863 to 1883,34 - at Novorosiisk University, 40 - at Kharkiv University (in particular, 18 at the Faculty of Physics and Mathematics, 12 at the Law Faculty, 9 at the Historical and Philological Faculty). In total, for example, 84 master's degrees were awarded at Kharkiv University during the given stage.

The adoption of the Statute in 1863 marked a new stage in solving the problem of academic staff training, in particular in the implementation of academic staff certification at universities. On the one hand, there were no significant changes in the procedure for obtaining degrees in comparison with the previous statutes, on the other hand the Statute of 1863 laid the foundation for further documents, regulating the mechanism of getting a degree in the future. In particular, the statute included only the appropriate for the autocracy minimum of regulations on scientific staff training, without which it was impossible to ensure the normal functioning of the universities, designed to serve primarily the needs of the state apparatus in the diplomaed specialists. The title of a full-time student 
was restored, and the procedure for getting a doctoral degree was changed. They did not have to take any exams, it was sufficient to conduct the public defense of the thesis ( $\S 111)$. The procedure for awarding a master's degree was also somewhat simplified. An important innovation was granting the right to the university council to approve the degrees and titles, which was previously held exclusively by the Minister of Education.

The Institute of Professorial Scholarship Holders became an effective form of academic staff training and formation of university teaching. Its legislative registration took place after the enactment of the university statute in 1863. The category of professorial scholarship holders included young people who were sent abroad for further training, as well as graduates, who were awarded scholarships and remained at universities if their theses could be prepared on the grounds of the materials from national archives and libraries. The right to choose the candidates rested on the faculty and university academic councils according to such criteria as good health, inborn talent, scientific achievements, pedagogical abilities, practical experience, perseverance in independent work, mastery of foreign languages. For example, candidate of natural sciences M. Bunge was chosen as a professorial scholarship holder at Kyiv University in 1865. He was distinguished by his persistence in chemistry studying, thorough knowledge in the subject and the ability to use experimental research techniques.

Particular attention should be paid to the "Regulations on scholarships for young people who have completed university courses and were left at universities to train for the professorship" (1868), aimed at regulating the training of young scientists left for scientific training at domestic universities. According to the document, professorial scholarship holders of the abovementioned category were to be selected by the faculty among the young people who had graduated with honors from a university course and expressed a desire to remain with the university and work on the further development of science. University academic councils approved the nominations of the suggested scholarship holders by 
means of a closed cast of votes. The scholarship allowance was established at 600 karbovanetses per year.

A faculty member was appointed to guide a scholarship holder. After six months he had to make the faculty aware of the applicants' progress on the grounds of his academic achievements. During the second year of study, the scholarship holder had to take the master's degree exams or submit a thesis. If the applicant fulfilled that requirement, the faculty could apply to the university academic council with the request to extend the term of the scholarship payment for another six months or a year.

The scholarship holders left at universities were allowed to attend the lectures of the professors for free and to use all scientific tutorials. If the faculty considered it necessary to send a scholarship student to another Russian university for some time, the latter, under the agreement of the rector, was transferred to the supervision of the corresponding faculty of that university.

According to the statistics, which was regularly outlined in the reports of the Ministry of Public Education, we state the fact that the practice of enrollment of professorial scholarship holders aimed at their training for a professor acquired a wide spread occurrence in Ukrainian universities during the 1870 s - early 1880 s. For example, in the period from 1864 to 1884,77 persons were enrolled at St. Volodymyr University, including 22 at the Faculty of History and Philology, 19 at the Faculty of Physics and Mathematics, 17 at the Medical Faculty. 26 persons took teaching positions, i.e. one third of the total number of professors; 15 persons became teachers of the given university. Due to the activity of the Institute of Professorial Scholarship Holders, graduates of the history and philology faculties of Ukrainian universities, such as D. Bahalii, M. VladymyrskyiBudanov, M. Drahomanov, V. Ikonnykov, I. Lynnychenko, I. Luchytskyi, F. Mishchenko (St. Volodymyr University); V. Buzeskul, A. Butsynskyi, M. Drynov (Kharkiv University); G. Afanasiev, M. Kondakov (Novorosiisk University).

According to the "Rules on the business trips of scholarship holders for scientific purposes abroad" (1867), students studying for 
master's degree, after successfully passing the exams, acquired the right to go abroad in order to prepare the thesis. There was a specific instruction which determined the list of subjects the applicant had to study, which institutions and universities he had to attend, the names of professors, whose lectures he had to listen to, as well as the timing and list of reporting documents.

The similar practice of arranging foreign scientific trips was introduced for privat associate professors in order to further ensure the educational process and students' research work under the guidance of highly qualified academic staff. Thus, the right to such trips was obtained by the following professors of St. Volodymyr University: hygienist V. Subotin, zoologist O. Paulson, specialists in trade law P. Tsytovych, O. Zahorovskyi and I. Tarasov, historian V. Piskorskyi, philologist M. Mandes, pharmacist D. Rodzaievskyi, specialist in nervous and mental illnesses M. Lapinskyi, philosopher G.-R.I. Yakubanis and others. ' .

During their foreign scientific trips, privat associate professors and professors had the opportunity to get acquainted with the scientific achievements and methods of teaching disciplines, to conduct complex research, to complete theses and scientific articles.

It is established that at the stage under research, the development of the institute of privat associate professorship was further developed. The associate professors, who replaced the adjuncts under the 1863 Statute, were freelance teachers who gave lectures (receiving rewards from "special sums" of the university) and, as a rule, were subsequently taken on the staff in the case of a vacancy for a professor. Therefore, privat associate professors were a certain natural resource for replenishing the university professorship.

${ }^{1}$ Tamozhska I. V. (2018) Obozrenie prepodavanija v Imperskom universitete Sv. Vladimira na 1895/96 uchebnyj god [Scientific trips of privat associate professors from pre-revolutionary Ukrainian universities to higher educational institutions and educational institutions in Western Europe]. Liudynoznavchi Studii. Drohobych. Is. 6/38. pp. 307-319. DOI: https://doi.org/10.24919/2313-2094.6/38.120914 
In the course of the scientific search it is established that the Statute of 1863 actually substantiated the legal justification of the privat associate professorship, and also proved the need for its extension. Privat associate professorship was considered as the most important tool against "stagnation and apathy", "to support the competition" between professors and associate professors, which would become an effective means of scientific-pedagogical training of teachers, a powerful incentive for their scientific and pedagogical activity. Moreover, the position of privat associate professor was also created to eliminate the excessive seclusion of the professorial corporation, to create a competitive environment, and most importantly - as a reserve of future professors.

The Statute adopted in 1863 facilitated the search for compromises in higher education policy between university academic staff and the government regarding the introduction of the position of privat associate professor. It was noted in the comments to this legislative act that the privat associate professorship would contribute to the increase of the number of professors among the academic staff, and would also become an effective means of the department replacing. Thus, the prospects of solving the staff problems in higher education were connected with the development of the institute of privat associate professorship, which agreed with the world practice. However, the number of privat associate professors was increasing too slowly during 20-year period following the adoption of the Statute.

The analysis of the mechanisms of university staffing in the Russian Empire could not be complete without assessing the role of the privat associate professorship as an extremely important factor in improving the quality of the scientific and methodological process. Less than three years after the adoption of the university Statute in 1863 , C. Woldemar drew some conclusions about the prospects for its effectiveness. At the same time, he appealed to M. Pyrohov's opinion, who critically and reasonably revealed the main shortcomings in the system of training and certification of academic staff (in particular, about filling vacant positions in the departments), 
problems with the restriction of universities' autonomous rights in this aspect. University academic councils, being typical corporate associations, because of the nepotism as well as the protection of their interests, constantly made biased decisions when addressing the issues affecting inferior-ranked teachers, in particular, privat associate professors. It is not by chance that C. Woldemar emphasized the need for an unlimited number of privat associate professors in universities, because under the conditions of the Russian Empire a dictatorial approach to pedagogical science was observed, especially in personnel policy. Therefore, it was impossible to secure the progress of this institute ${ }^{2}$.

The 1863 Statute also allowed candidates to apply for privat associate professorship (under the 1843 decree, applicants were required to have a "master's degree"), which was a fundamentally important decision that opened privat associate professorship to the widest possible range of people (at the medical faculty, where there was a parallel system of degrees, even doctors were allowed to be admitted to privat associate professorship).

An increase in the number of associate professors was to become a "fresh-water force", "a natural means of filling professors" vacancies", "the nursery for professors". These statements fully coincided with M. Pyrohov's opinion, who argued for the need for mass involvement of privat associate professors in teaching as an important measure in the way of modernizing universities, creating an atmosphere of scientific search there.

${ }^{2}$ Woldemar C. (1866) Beiträge zur Geschichte und Statistik der Gelehrten und Schulanstalten des Kaiserlich Russischen Ministeriums der Volksaufklärung nach officiellen Quellen bearbeitet von C. Woldemar. III Theil. Wortlaut und Erläuterung der neuesten Statuten und Etats der unter dem Ministerium der Volksaufklärung stehenden Universitäten und Gimnasien sowie eines Reglaments über dieVolksschulen. St. Petersburg: Gedruckt bei Röttger und Schneider, 445 s.

3 University printing house (1864) Akt v Imperatorskom Har'kovskom universitete 17 janvarja 1864 goda [Regulations in Emperor Kharkov University of January,17 1864], Kharkov : University printing house. 37, 44, 7 p. 
In the course of the research it was found out that the university Statute of 1863 influenced the new "Regulations on the awarding of academic degrees and titles" created in 1864, which took into account many proposals by university professors aimed at changing the existing system of scientific staff certification.

According to the "Regulations", university academic councils had to develop rules on the term and procedure of examinations for academic degrees and titles. It was found out that the adoption of such rules involved intense struggle of progressive and reactionary forces, which occurred at all levels - in university academic councils, between the trustees and councils, and even inside the Scientific Committee itself.

Kharkiv University Council suggested that the examinee should provide the faculty with "full lecture notes of the main subjects of the exam", considering that "such an order would serve the faculty as one of the most effective ways of outlining the degree of ... a master's scientific education". The trustee of the Kharkiv Educational District believed that the exams had to be conducted in a regulated way as before, in accordance with the programs made by the faculty. Scientists from St. Volodymyr University also sent their proposals. For example, with regard to the "exam" on the candidate's degree, it was suggested that the time required to submit a written "reflection" should be increased (instead of three months allotted for the preparation of this type of work, a 6-month period was suggested). Scientists from St. Volodymyr University also suggested reintroducing exams for the degree of doctor of sciences, which had been cancelled before. They emphasized that the presentation and public defense of a thesis "... may not always be sufficient to assess the independence and thorough training of the examinee". The project made by Kharkiv University was adopted as a standard of the rules on the term and procedure of examinations for academic degrees and titles and recommended as an example to other universities.

According to the Statute of 1863, applicants for the position of privat associate professor were required to submit a dissertation 
provenialegendi ("to be admitted to lectures"), different from the thesis for a scientific degree, and publicly defend it. In terms of scientific complexity the provenialegendi was much simpler than a master's thesis. At the same time, it should not have been reduced to translation, to contain errors, but to have a level of minor but scientific work.

For applicants known to the university, the procedure of the submission and defense of the dissertation was often a formality. However, it was strictly obligatory for everyone. There were a few serious scientific works among the dissertations, several upgraded candidate's or even student's works, some applicants used their works written or even published long ago. For example, M. Drahomanov presented as a dissertation his former work "On Emperor Tiberius", in which he drew radical conclusions severely criticized by his opponents; V. Sokalskyi, a privat associate professor at Kyiv University, also used his student work. Specially written works were far less defended as provenialegendi dissertations.

The defense could be held at any university, and the resulting teaching rights were extended to all higher educational institutions. Thus, Kharkiv University candidate N. Kuplevaskyi was sent to Kyiv and defended his dissertation there, then he returned to Kharkiv and began teaching as a privat associate professor. In other cases the place of the defense was determined by the willingness of the university to subsequently employ a privat associate professor. For example, A. Borovykovskyi, candidate of Law Faculty at Kharkiv University, presented his provenialegendi at his university, and then moved to Moscow and defended his dissertation there.

As a rule, faculties did not make high demands for the level of the dissertation, because even the "deadly" reviews did not mean an unavoidable failure. However, the admission of a new member to the teaching corporation was a difficult process, so defending the thesis as a condition of admission could become a heated debate.

It was found out that Kharkiv University had stricter requirements for the dissertation. According to the conclusion of the Faculty of Law (1870), the dissertation provenialegendi could not be 
equated with the candidate's work; the work had to show a thorough knowledge of the subject and literature, soundness and clarity of judgment. Consequently, there were a few cases of failed defenses at that faculty: out of 16 dissertations presented from 1863 to 1884, four were declared unsatisfactory.

The university Statute of 1863 introduced conducting two trial lectures for candidates for privat associate professorship, in case "their teaching abilities were not well-known", which made it more difficult for outside candidates to access the institute.

However, for those who passed this test, conducting the trial lectures proved to be an extremely important moment at the beginning of their teaching career. The topic of one of the lectures was chosen by the candidate himself, the other one was appointed by the faculty at a special meeting. If the dissertation defense was a more formal procedure aimed at convincing the university council of the author's competence and erudition, the trial lectures were intended to reveal the candidate's pedagogical abilities. The dissertation was prepared in advance, its content was adjusted. The topic of one of the two trial lectures was determined by the faculty to test the applicant's ability to quickly collect, summarize and present the material in the form of a lecture. Moreover, trial lectures were given to an audience of students - the privat associate professor's future trainees, who he had to make interested in his subject. Trial lectures were an effective method of teachers' scientific and pedagogical training, testing of their professional knowledge and skills in practice. Some of the professors of the relevant faculty could also attend the lectures. Thus, Professor O. Kistiakivskyi visited the trial lectures of M. Kuplevaskyi (a privat associate professor at St. Volodymyr University in 1877-79).

According to the professors' statements, the lectures on the topic chosen by the candidate himself, were, on the contrary, characterized mainly by the scientific style of presentation, the large number of references to sources and literature, including foreign and modern ones, as well as the use of the results of the candidate's own research. Among the disadvantages of the lectures on the topic 
assigned by the faculty, we could mention literary techniques, rhetorical skills and broad generalizations.

Entrance examinations for the title of privat associate professor, introduced at the universities at the stage under research, were a serious trial for young scientists. Not all candidates who formally met the requirements were successful. At the same time, by order of the Minister of March 8, 1875, a legislative framework was created to involve privat associate professors in more intensive teaching. Since then, cases of appointing privat associate professors to vacancies in the departments had been recorded.

The simplification of the procedure for obtaining scientific degrees, the elimination of the doctoral exam in accordance with the "Regulations on the awarding of academic degrees and titles" (1864) significantly intensified the scientific work and teaching activity in domestic universities, which had a positive impact on academic staff training. During the decade (1863-1874), about 180 master's and doctoral theses were defended at Kharkiv, Kyiv and Novorosiisk universities. The significant feature of the stage lied in the fact that scientific certification became a purely internal affair of a particular university, which, in turn, contributed to transforming the academic councils into the "highest authority institutions" in terms of awarding scientific degrees. For example, from 1863 to 1883 the academic council of St. Volodymyr University awarded the master's degree and doctorate to 113 persons, including the master's degree to 39 applicants, doctor's to 74, while only 80 applicants got the degrees in the first 29 years of the university's operation. In the period from 1866 to 188421 persons obtained the doctoral degree and 24 persons were awarded the master's degree at Novorosiisk University.

\section{Evolutionary development of theoretical and methodological foundations for academic staff training in domestic universities (1884-1900)}

At the second stage (1884-1900) the basic principles of realization academic staff training in the domestic universities were 
regulated by the provisions of the University Statute of 1884, which remained practically unchanged till the end of the century, supplemented only by ministerial circulars.

It is established that the Statute of 1884 made some changes to the procedure for awarding scientific degrees. The provisions of Chapter Two "Trial" of the third part of the Statute abolished the candidate's degree and introduced a two-stage system: master-doctor, which were awarded at all faculties except medical, where there was only a doctor's degree.

On the basis of the Statute of 1884, the postgraduate, who passed the exams and conducted two trial lectures (one at his own request, the other at the appointment of the faculty), acquired the right to teach in the rank of a privat associate professor, which allowed "diagnosing the applicant's ability and suitability to the future teaching career in advance".

According to the provisions of the Statute, the greater role was played by the trustee, who at his or her own order could convene the council, the board, the assembly of faculties; be present at their meetings, appoint deans of faculties, introduce extraordinary professors to the Minister of Public Education for their promotion, and monitor private associate professors' teaching. The Minister of Public Education himself now appointed the rector, who became the "presiding person". In accordance with the provisions of the Statute of 1863, the Rector was obliged to report to the University Council in case of a "teaching irregularity". On the contrary, the Statute of 1884 gave the rector the right to make instructions, warnings and reproofs.

In the course of the research it was found out that the new university statute significantly complicated the procedure for awarding degrees. More attention was paid to purely formal issues - taking exams, preliminary consideration of theses at the faculties, etc. According to the Statute of 1884, the number of degrees decreased significantly. There were now two degrees (master's and doctor's) in all faculties, except medical, the rest were awarded diploma of I or II level. In addition, the Statute of 1884 significantly increased the Ministry's control over the process of scientific staff certification. 
Thus, the Minister could appoint the examiners, who were to be present at the examinations for awarding a scientific degree on the corresponding field of science.

In 1884, the Ministry of Public Education developed new "Rules" for the functioning of the Institute of Professorial Scholarship Holders, according to which the head of the department or the dean of the faculty were responsible for searching scholars. The former were obliged to take all necessary measures to train promising young people in the best way possible, above all at those departments which were considered to be major in the faculty, or which experienced the lack of staff.

Applicants could become professorial scholarship holders if they met the following requirements: a model certificate with excellent marks in ancient languages (for candidates of historical and philological or legal sciences) or in mathematics and physics (for candidates of physical and mathematical or medical sciences); command of foreign languages to be able to study professional literature and master lecture material; high marks in major subjects of the department; their own scientific works; perfect moral qualities; the ability to reasonably express their opinions, good health. From now on, the Ministry of Public Education decided where the scholarship holder's internship would take place (in Russia or Europe) and appointed scientific advisors who could make changes to the academic curriculum according to the candidate's inclinations and needs; clear deadlines were set for the applicants to submit a plan or instruction for faculty-designed classes, as well as a certificate of political credibility.

Despite the strengthening of government control, 24 scholarship holders became teachers at Kharkiv University during 1884-1894. The Institute of Professorial Scholarship Holders was particularly effective at St. Volodymyr University, where 87 scholars were trained during the decade.

The innovation in solving the personnel problem at the stage was the creation of the institute of full-time associate professors according to the German model as "center of future forces of universities' scientific corporation". However, this institution, 
introduced by the university Statute of 1884, did not root deeply in the Russian Empire due to unfavorable conditions for potential applicants for this title, so it was soon abolished.

The Statute of 1884 significantly changed the nature of the privat associate professorship. "Professors of other higher educational institutions, as well as persons who gained popularity with their scientific works ..." could become privat associate professors. In fact, privat associate professorship was an opportunity for scholars to continue teaching on a freelance basis.

The number of privat associate professors fluctuated every year. Thus, at the beginning of 1888 there were 31 privat associate professors at St. Volodymyr University, and in September of the same year only 24 . They conducted classes at 10 vacant departments, only at the department of trade law there was a professor of civil law. The faculties obliged the privat associate professors to acquire scientific and pedagogical knowledge, and then decided whether they could be trusted to examine students, what reward they should get and even the priority of rewarding.

After 1884, the conditions for admission to the privat associate professorship became more flexible in the whole. The most significant change in obtaining the rank of a privat associate professor was the abolition of the mandatory defense of the dissertation provenialegendi, which by that time had become a formality and did not cause any difficulties.

The charter of 1884 abolished the position of associate professor. Associate professors known for their erudition were either promoted to extraordinary professors, or, "if their teaching was found to be useful", they were left in the position of associate professors temporarily, with an annual extension. With the abolition of the associate professorship, the hierarchy of positions looked like this: freelance privat associate professors, full-time extraordinary and ordinary professors. This system left the only possible option for those who would like to teach in anticipation of a full-time position. It was a privat associate professorship. Therefore, the position of a privat associate professor became the main way to attain the professorship. 
That fact marked an important change in the tasks of the privat associate professorship - "it transformed from the alternative and financially unprofitable option of a career start it became the only opportunity to gain a foothold at university". The Statute of 1884 also maintained the tradition of involving privat associate professors in conducting lectures at vacant departments on a temporary basis. However, it had to be permitted by the Minister, the privat associate professor got the reward, which could not be more than a half of an ordinary professor's salary. Such replacement should not have taken more than a year.

The tasks of the privat associate professorship were finally established: training for the professorship through pedagogical practice, stimulation of competition among teachers aimed at increasing their scientific and teaching level, maximum expansion of the curriculum of the academic disciplines, radical revival of the very scientific spirit of universities.

The study of scientific sources and archival materials made it possible to find out that a large number of teachers from domestic universities were thoroughly trained in privat associate professorship. In this regard it is worth mentioning bright graduates of the history and philology faculties of Ukrainian universities, whose names have become the true pride of national science: D. Bahalii, M. Vladymyrskyi-Budanov, S. Hohotskyi, M. Dashkevych, M. Drahomanov, V. Ikonnikov, O. Kistiakivskyi, I. Luchytskyi, F. Mishchenko, I. Lynnychenko, G. Pavlovskyi and others (St. Volodymyr University); V. Buzeskul, A. Butsynskyi, M. Drinov, I. Sreznevskyi and others (Kharkiv University); M. Kondakov, G. Afanasiev and others (Novorosiisk University).

Due to the intensification of the research activity of masters and privat associate professors, which was one of the main factors for improving the professional level, their role significantly increased in the educational process of universities. In addition, teachers participated in the work of scientific societies. This, in particular, is testified by the study of archival materials at Kyiv University: privat associate professors participated in the work of the Kyiv Law Society 
(O. Zhylin), the Joint-Stock Company (B. Shyshkovskyi; Paris); XVII International Medical Congress in London (M. Strazhesko); Kiev Syphilidological and Dermatological Society, Society of Kyiv Physicians (S. Tomashevskyi), Historical Society of France (V. Piskorskyi), conducted advanced training courses for teachers and doctors.

University teachers published a great deal of articles in the University Newsletter. For example, Master of Police Law I. Tarasov presented his impressions of being in educational institutions of Germany, Austria-Hungary, Switzerland, and also outlined the activity of loan societies, cooperative structures in five issues of the edition for $1879^{4}$. An essay by A. Hren about the history of the Caucasus isthmus, which analyzed the literary and archival materials on the history of the Caucasus, and also described the geographical position of this region, was published in two issues in $1895^{5}$.

Academic staff of domestic universities also included professors invited from other universities of the Russian Empire. However, the tendency gradually emerged to develop the scientific and pedagogical potential of Ukrainian universities due to the improvement of their own graduates' training. It is significant that at the end of XIX century $43 \%$ of the faculty members of Kharkiv and almost half of St. Volodymyr University were alma mater students, which proved the efficiency of masters and privat associate professors training at domestic universities.

Since 1884, the regulations on trial lectures had undergone significant changes, and conducting such lectures had ceased to be a

${ }^{4}$ Tarasov I. T. (1879) Dva goda na Zapade s uchjonoju cel'ju [Two years in the West for a scientific purpose]. University Newsletter. № 1. pp. 28-50; Tarasov I. T. (1879) Dva goda za granitseyu [Two years abroad]. University Newsletter. № 5. P. 326-360; Tarasov I. T. (1879) Dva goda za granitseyu [Two years abroad]. University Newsletter. № 7. pp. 463-499; Tarasov I. T. (1879) Dva goda za granitseyu [Two years abroad]. University Newsletter. № 8. pp. 539-566.

${ }^{5}$ University Newsletter (1895) Obozrenie prepodavaniya $\mathrm{v}$ Imperskom universitete Sv. Vladimira na 1895/96 uchebnyy god [Teaching review St. Vladimir Imperial University for 1895/96 academic year] (K.). № 9. pp. 1-72. 
prerequisite for some candidates. Overseas trips "for a scientific purpose" remained an effective means of academic staff training.

At the stage under research, university academic councils became an intermediate instance of educational affairs between the trustee and the faculties. At the same time, the Statute of 1884 retained the right of academic councils to approve scientific degrees and to apply for the opening of scientific societies at the university.

A significant drawback of this stage was the formalization of the procedure for awarding scientific degrees and the absorption of academic councils' functions by other management structures, which negatively affected academic staff training.

\section{CONCLUSIONS}

The greatest positive influence on the solution of the problem of academic staff training in the domestic universities during the researched period was made by the Statute of 1863 , when due to the democratic reforms of the 1860s universities acquired broad powers and the right to independently determine the development strategy of the university, in particular, to increase the scientific and pedagogical level of the teaching staff. The main official documents, in accordance with which academic staff certification was conducted in Ukraine during the researched period, included: university statutes, developed by universities, regional rules on the procedure and terms of conducting examinations for academic degrees and the "Regulations for awarding academic degrees". They set out the general procedure for awarding scientific degrees, a more detailed regulation of the procedure for getting a degree was outlined in the published "Regulations".

The analysis of scientific sources and archival materials gives the grounds for the conclusion: if the direct and obvious task of the privat associate professorship - training for the professorship coincided with the task performed by the institute of professorial scholarship holders, the fundamental difference and peculiarity of the privat associate professorship was the combination of the privateassociate scientific and pedagogical activity by privat associate 
professors as the Ministry of Education and the universities tried to provide an opportunity for privat associate professors to not only give lectures on their own private programs that supplemented the core course, but also and to take part in teaching alongside with the professors.

The activities of Kharkiv, Kyiv and Novorosiisk universities aimed at the organization of academic staff training involved: 1) preliminary interview with candidates; 2) convening faculty meetings in order to develop the current rules on the terms and procedure of masters training, to carry out the certification of applicants on major and optional subjects; 3) conducting the procedure of postgraduates' and privat associate professors' theses public defense, selection of postgraduates and privat associate professors for internships abroad and hearing their reports; 4) conducting trial lectures, etc.

In accordance with the theoretical and methodological principles of the research, academic staff training in Ukrainian universities during the given was studied as a complex and continuous process that took place under the influence of socio-political, socioeconomic as well as cultural and educational determinants.

\section{SUMMARY}

The experience of academic staff training in St. Volodymyr University, Kharkiv University and Novorosiisk University during 1863-1900 is summarized. The stages of the solution of the abovementioned problem within the specified chronological framework are singled out: I stage (1863-1883) - a stage of expanding the content and areas of academic staff training in the context of the current university reforms, II stage (1884-1900) - a stage of evolutionary development of theoretical and methodological foundations for academic staff training in domestic universities. The legislative environment, peculiarities and directions of academic staff training in Ukrainian universities after the adoption of the university Statute of 1863 are outlined. It is determined that the regulatory and legal framework that regulated academic staff training and 
certification in Ukrainian universities during the researched period included laws (university statutes, decrees) and by-laws (orders, decrees, circulars, instructions, rules).

\section{REFERENCES}

1. University printing house (1864) Akt $\mathrm{v}$ Imperatorskom Har'kovskom universitete 17 janvarja 1864 goda [Regulations in Emperor Kharkov University of January,17 1864], Kharkov : University printing house. $37,44,7 \mathrm{p}$.

2. Woldemar C. (1866) Beiträge zur Geschichte und Statistik der Gelehrten - und Schulanstalten des Kaiserlich Russischen Ministeriums der Volksaufklärung nach officiellen Quellen bearbeitet von C. Woldemar. III Theil. Wortlaut und Erläuterung der neuesten Statuten und Etats der unter dem Ministerium der Volksaufklärung stehenden Universitäten und Gimnasien sowie eines Reglaments über dieVolksschulen. St. Petersburg: Gedruckt bei Röttger und Schneider, $445 \mathrm{~s}$.

3. University Newsletter (1895) Obozrenie prepodavaniya $v$ Imperskom universitete Sv. Vladimira na 1895/96 uchebnyy god [Teaching review St. Vladimir Imperial University for 1895/96 academic year] (K.). №9. pp. $1-72$.

4. Tamozhska I. V. (2018) Obozrenie prepodavanija v Imperskom universitete Sv. Vladimira na 1895/96 uchebnyj god [Scientific trips of privat associate professors from pre-revolutionary Ukrainian universities to higher educational institutions and educational institutions in Western Europe]. Liudynoznavchi Studii. Drohobych. Is. 6/38. pp. 307-319. DOI: https://doi.org/10.24919/ 2313-2094.6/38.120914

5. Tarasov I. T. (1879) Dva goda na Zapade s uchjonoju cel'ju [Two years in the West for a scientific purpose]. University Newsletter. № 1. pp. 28-50.

6. Tarasov I. T. (1879) Dva goda za granitseyu [Two years abroad]. University Newsletter. № 5. P. 326-360.

7. Tarasov I. T. (1879) Dva goda za granitseyu [Two years abroad]. University Newsletter. № 7. pp. 463-499. 
8. Tarasov I. T. (1879) Dva goda za granitseyu [Two years abroad]. University Newsletter. № 8. pp. 539-566.

\section{Information about the author: Iryna Tamozhska,} Candidate of Pedagogical Sciences, Associate Professor at the Language Training Department 1 of the Institute of International Education for Study and Research, V.N. Karazin Kharkiv National University in Ukraine 4, Maidan Svobody, Kharkiv, 61022, Ukraine ORCID ID: orcid.org/0000-0003-0865-2380 